\title{
PENGARUH GOOD CORPORATE GOVERNANCE DAN LEVERAGE TERHADAP KINERJA KEUANGAN PERBANKAN YANG TERDAFTAR DI BURSA EFEK INDONESIA
}

\author{
Elvina Agustin, Aminar Sutra Dewi \\ Sekolah Tinggi Ilmu Ekonomi KBP \\ elvinaagustin1908@gmail.com
}

\begin{abstract}
The financial performance of State-Owned Enterprises has decreased from 2015 to Q1 2016 because of rising NPLs or bad loans. The role of the organization in the company will give effect to the financial performance. This study aims to determine the influence of the Board of Commissioners, Audit Committee, and Leverage on Performance Banking finance. The sample used is the financial sector companies in the year 20012-2016 amounted to 45 samples. The type of data used is secondary data. The hypothesis in this research is tested by using panel data regression analysis. The result of the hypothesis test shows that the board of commissioners has negative and insignificant effect, the audit committee has positive and insignificant impact on the company's financial performance (ROA). Leverage has a negative and insignificant impact on ROA.
\end{abstract}

Keywords: Board of Commissioners, Audit committe, Leverage, and ROA.

\section{PENDAHULUAN}

Banyaknya hambatan-hambatan yang terjadi pada perusahaan perbankan termasuk bank milik BUMN, Seperti terjadi terhadap kinerja keuangan bank BRI,BNI,Mandiri BTN yang menurun dari tahun 2015 ke triwulan bulan 1 tahun 2016 hal ini disebabkan oleh meningkatnya Non Perfoming Loan (NPL) bank dan terhambatnya laju terhadapkredit. Peningkatan NPL ini dikarenakan banyaknya debitor di sektor pertambangan yang kolaps sehingga dana yang dipinjamkan pada bank tidak dapat dilunasi. Selain itu, untuk menjaga kepercayaan investor maka kesehatan suatu bank harus tetap dijaga. Seperti kasus bank BUMN di atas akibat dari turunnya laba perbankan berdampak pada perusahaan lainnya yang mana investor akan mengambil semua asset nya dan akan berpindah pada investasi lainnya seperti pembelian Surat Berharga Negara (SBN).

Untuk menjaga investor agar asset nya tidak ditarik dari perusahaan perlunya Good Corporate Governance untuk melakukan pengawasan dan memberikan jaminan terhadap stake holders, termasuk didalamnya adalah shareholders, lenders, employees, government, executives costumer dan stakeholders yang lain. Namun dalam kekrisisan pemimpin di Negara 
Indonesia peran GCG ini sangat dibutuhkan agar dapat membantu mengelola kerja perusahaan dengan baik. Selain itu yang utama jaminan atas hak stake holder untuk mendapatkan informasi yang tepat dan benar.

Terdapat satu hal yang tidak dapat dipisahkan dalam menghubungkan struktur kepemilikan dengan kinerja pada bank. Yaitu kepengurusan dalam manajemen bank itu sendiri. Oleh sebab itu hubungan antara manajemen suatu bank dengan pemilik bank akan dibentuk dalam suatu kontrak (performance contract).yaitu kesepakatan antara pemilik saham serta dengan manajemen perusahaan tersebut akan sejalan dengan Agency Theory (Jensen dan Meckling, 1976).

Dewan Komisaris merupakan orang yag utama dalam menjalankan system tata kelola yang terdapat didalam perusahaan.perannya diharapkan untuk dapat meningkatkan laba perusahaan. Meskipun keberadaan dewan komisaris memberikan pengaruh yang baik terhadap kinerja perusahaan yank dapat dilihat dari jumlahnya. Banyak atau tidaknya jumlah komisaris memiliki kontribusi terhadap perusahaan. Berdasarkan penelitian yang dilakukan oleh Ika yulianawati (2014) yang melakukan studi empiris terhadap perusahaan yang melakukan kecurangan dengan yang tidak melakukan kecurangan dengan persentase dewan komisaris memiliki signifikansi yang lebih rendah. Sehingga dapat ditarik Hipotesis Pertama bahwa jumlah dewan komisaris dapat berpengaruh posotif dan signifikan terhadap kinerja keuangan.

Selain itu, komite audit merupakan orang yang bertugas dewan komisaris dalam melakukan pengawasan terhadap kinerja keuangan perusahaan. Pengukuran komite audit juga dapat dilakukan dengan mengukur tingkat jumlah komite audit yang di angkat oleh dewan komisaris. Dengan keberadaan komite audit diharapkan dapat membantu mengawasi proses akuntasi dan pelaporan keuangan agar dapat mengurangi perilaku menejer terhadap kecurangan yang mungkin dapat dilakukan. Dalam penelitian yang dilakukan oleh Maria Fransisca Widyawati (2013) yang mengatakan bahwa keberadaan komite audit tidak memiliki pengaruh yang signifikan terhadap kinerja keuangan perusahaan. Yang artinya keberadaan komite audit tidak menjamin keefektifan suatu kinerja. Sehingga dapat ditarik Hipotesis Kedua bahwa komite audit memiliki pengaruh positif dan tidak signifikan terhadap kinerja keuangan perusahaan.

Untuk menjalankan perusahaan GCG berperan dalam menjalankan perusahaan serta memikirkan darimana tingkat biaya operasional didapatkan salah satunya ialah dengan melakukan peminjaman modal asing yang disebut juga dengan Leverage. Tingkat hutang yang tinggi akan menurunkan laba dari suatu perusahaan . menurut penelitian Dian Agustia (2014) mengatakan kinerja perusahaan yang di biayai dengan hutang akan memberikan pengaruh yang negative terhadap kinerja keuangan. Karena apabila tingkat hutang lebih tinggi dibandingkan dengan aktiva maka akan cenderung melakukan manipulasi terhadap laporan keuangan. Sehingga dapat ditarik Hipotesis ketiga bahwa Leverage berpengaruh negative dan signifikan terhadap kinerja perusahaan. 


\section{METODE PENELITIAN}

Penelitian ini termasuk pada penelitian kuantitatif yang mana ada angka-angka yang terdapat pada penelitian ini. penelitian kuantitatif menggunakan skala numeric, berbasis pola alur deduktif, dimana untuk menjawab rumusan masalah digunakan teori atau konsep untuk dapat merumuskan hipotesis.Populasi merupakan suatu wilayah generalisasi yang terdiri dari objek yang mempunyai kuantitas dan karakteristik tertentu yang ditetapkan oleh peneliti untuk di pelajari dan kemudian ditarik kesimpulannya.Oleh karena itu dapat disimpulkan bahwa populasi dapat berupa subyek (orang) ataupun objek (tempat) yang karakteristik berbeda dan bisa diteliti. Dalam penelitian ini peneliti mengambil populasi pada 43 perusahaan yang terdaftar di Bursa Efek Indonesia., populasi yang ada akan diambil sejumlah tertentu sebagai sampel. Pengambilan sampel penelitian dilakukan dengan metode purposive sampling. sedangkan untuk teknik pengumpulan data didapat melalui Dokumentasi yang mana data bisa di dapat pada situs resmi Bursa Efek Indonesia yang telah memplubikasikan ringkasan kinerja keuangan berdasarkan objek yang dibutuhkan.

\begin{tabular}{|c|c|c|c|}
\hline VARIABEL & PENGERTIAN & INDIKATOR & SUMBER \\
\hline $\begin{array}{l}\text { Kinerja } \\
\text { Keuangan }\end{array}$ & $\begin{array}{l}\text { Kinerja Keuangan } \\
\text { Adalah pencapaian } \\
\text { prestasi perusahaan } \\
\text { pada suatu periode } \\
\text { yang } \\
\text { menggambarkan } \\
\text { kondisi kesehatan } \\
\text { keuangan } \\
\text { perusahaan. }\end{array}$ & $\begin{array}{l}C F R O A= \\
\frac{\text { Keuntungan Bersih }}{\text { Jumlah asset }}\end{array}$ & $\begin{array}{l}\text { Maria } \\
\text { Fransisca } \\
\text { Widyati } \\
(2013)\end{array}$ \\
\hline $\begin{array}{l}\text { Dewan } \\
\text { Komisaris }\end{array}$ & $\begin{array}{l}\text { Dewan Komisaris } \\
\text { adalah Organ } \\
\text { Perseroan yang } \\
\text { bertugas melakukan } \\
\text { pengawasan secara } \\
\text { umum dan/atau } \\
\text { khusus sesuai } \\
\text { dengan anggaran } \\
\text { dasar serta memberi } \\
\text { nasihat kepada } \\
\text { Direksi. }\end{array}$ & Jumlah Dewan komisaris & $\begin{array}{l}\text { Maria } \\
\text { Fransisca } \\
\text { Widyati } \\
(2013)\end{array}$ \\
\hline \multirow[t]{2}{*}{$\begin{array}{l}\text { Komite } \\
\text { Audit }\end{array}$} & $\begin{array}{lr}\text { Komite } & \text { Audit } \\
\text { Adalah sekelompok } \\
\text { orang yang dipilih } \\
\text { oleh } & \text { dewan } \\
\text { komisaris untuk } \\
\text { mengerjakan } \\
\text { pekerjaan tertentu. }\end{array}$ & Jumlah komite audit & $\begin{array}{l}\text { Maria } \\
\text { Fransisca } \\
\text { Widyati } \\
(2013)\end{array}$ \\
\hline & Leverage adalah & & Ika \\
\hline
\end{tabular}




\begin{tabular}{|c|c|c|c|}
\hline Leverage & $\begin{array}{lr}\text { suatu } & \text { kebijakan } \\
\text { yang } & \text { dilakukan } \\
\text { oleh } & \text { suatu } \\
\text { perusahaan } & \text { dalam } \\
\text { hal } & \\
\text { menginvetasikan } \\
\text { dana rang } \\
\text { memperoleh atau } \\
\text { sumber dana yang } \\
\text { disertai dengan } \\
\text { adanya beban/biaya } \\
\text { tetap yang } & \text { harus } \\
\text { ditanggung } & \\
\text { perusahaan. } & \text { Levera } \\
\text { ge diukur } & \text { dengan } \\
\text { tingkat } & \text { hutang } \\
\text { perusahaan. }\end{array}$ & $D E R=\frac{\text { Total Hutang }}{\text { Total Modal }}$ & $\begin{array}{l}\text { Yulianawati } \\
(2014)\end{array}$ \\
\hline
\end{tabular}

\section{Teknik Analisis Data}

Teknik analisis data yang digunakan dalam penelitian ini adalah metode analisis statistik. Analisis data menggunakan EVIEWS 8, yang dimana teknik analisis data yang digunakan oleh peneliti adalah:

\section{Statistik Deskriptif Analisis}

Statistik deskriptif adalah penyajian data secara numerik. Statistik deskriptif menyajikan ukuran-ukuran numerik yang sangat penting bagi data sampel. Statistik deskriptif juga digunakan untuk mengetahui nilai rata-rata, minimal, maksimal dan standar deviasi dari variabel-variabel yang diteliti.

\section{Uji asumsi klasik}

\section{Uji Normalitas}

Uji normalitas menggambarkan apakah dalam model regresi, variabel penganggu atau residual terdistribusi normal. Namun Pada penelitian ini menggunakan uji statistik Jarque-Bera untuk mengetahui apakah data berdistribusi normal. Data dikatakan normal apabila JarqueBera lebih kecil dari 2 (tidak signifikan) atau profitabilitas lebih besar dari $\alpha 5 \%(0,05)$ maka data terdistribusi normal.

\section{Uji Multikolinieritas}

Uji multikolinieritas diguna untuk mengetahui adakah indikasi asumsi klasik tersebut. Dapat dilihat apakah model regresi tersebut terdapat korelasi antara variabel bebas atau variabel terikat. Apabila memiliki independen lebih dari satu. Syarat tidak terjadi Multikolinieritas adalah jika nilai korelasi antar variabel independen $<0,8$. Jika nilai korelasi > 0,8 maka terjadi multikolinieritas.

\section{Uji Heteroskedastisitas}

Uji heteroskedastisitas adalah uji yang bergunakan untuk mengetahui didalam model regresi apakah ditemukan ketidaksamaan antara variasi dari residual antara objek satu dengan objek lainnya. 
Terjadinya kondisi heteroskedastisitas akan berakibat tidak mutlaknya penaksiran koefisien seperti berkurang atau berlebih dari yang semestinya.uji Rank Sparman digunakan Untuk menguji ada tidaknya heteroskedastisitas, melihat gejala heteroskedastisitas dalam data.dengan cara mengkorelasikan masing-masing nilai absolut yang residual terhadap variabel independent. Gajala ini dapat dilihat dari nilai residual yang signifikan. Apabila nilai absolute nya signifikan maka data memiliki gejala heteroskedastisitas.

\section{Uji Autokorelasi}

Observasi yang berurutan sepanjang waktu antara satu sama lain akan memunculkan gejala autokorelasi. Masalah autokorelasi timbul karena adanya residual tidak bebas dari suatu observasi ke observasi lainnya (Mardiyati et al,2012). Uji D-W dapat digunakan untuk melihat adanya penyakit autokorelasi. Batas nilai dari metode Durbin-Watson adalah: (1) nilai D-W yang besar atau diatas 2 berarti tidak ada autokorelasi negatif. (2) nilai D-W antara negatif 2 sampai 2 berarti tidak ada autokorelasi atau bebas autokorelasi. (3) nilai D-W yang kecil atau dibawah negatif 2 berarti ada autokorelasi.

\section{Analisis Regresi data panel}

Data yang digunakan dalam penelitian ini adalah data sekunder yang didapatkan dari Bursa Efek Indonesia yang telah dipublikasikan. Data yang digunakan merupakan data benar-benar tanpa ada manipulasi. yang secara tidak langsung didapatkan dari situs resmi keuangan perbankan.berikut uji kecocokan model yang didapatkan dalam analisis regresi data panel. Analisis ini merupakan kombinasi antara data runtun waktu dan data cross section.

Saat dilakukan pengujia uji chow untuk memilih antara penggunaan Effect Common dengan Efect Fixed dan uji Hausman untuk memilih antara Uji fixed dengan Uji Random.

\section{Common effect model (CEM)}

Model common effect model merupakan model sederhana yaitu dengan menggabungkan seluruh data time series dengan cross section, selanjutnya digunakan estimasi model dengan menggunakan OLS(Ordinary Least Square). Metode analisis ini berlaku untuk semua objek yang akan diteliti. Namun kelemahan model ini adalah ketidaksesuaian model dengan keadaan yang sebenarnya.

\section{Fixed effect model (FEM)}

Model data panel dengan fixed effect model mengasumsikan bahwa perbedaan mendasar antara individu dapat di akomodasikan melalui perbedaan intersepnya antar waktu sama.intersep individu merupakan intersep yang tidak dapat diketahui dan akan di estimasi. Pada umumnya memasukkan variabel Dummy variable.

\section{Random Effect Model (REM)}

Random Effect Model digunakan untuk mengatasi kelemahan model efeect tetap yang menggunakan Dummy Variabel. Sehingga 
model mengalami ketidakpastian. Penggunaan dummy variabel akan mengurangkan derajat bebas yang pada akhirnya akan mengurangi efisiensi dari parameter yang diestimasi. REM menggunakan residual yang diduga memiliki hubungan antarwaktu dan antar individu.sehingga REM mengasumsikan bahwa setiap individu memiliki perbedaan intersep yang merupakan variabel random.

\section{Uji Hipotesis}

\section{Uji F ( Uji Simultan)}

Uji Hipotesis ini berguna untuk menguji atau memeriksa apakah koefisien regresi yang terdapat perbedaan nyata yang signifikan. Pada penelitian ini nilai F-hitung akan dibandingkan dengan F-tabel 1 pada tingkat signifikan $(\alpha)=5 \%$ (Erari 2014)

\section{Uji t (Uji Parsial)}

Pengujian ini menggunakan tingkat $0,05(\alpha=5 \%)$ atau nilai signifikan. Hipotesis dapat di terima atau ditolak: (1) jika nilai signifikansi $\mathrm{t}>0,05$ maka hipotesis ditolak (koefisien regresi tidak signifikan). (2) jika nilai signifikansi $\mathrm{t} \leq, 5$ hipotesis diterima (Koefisien regresi signifikan)

\section{HASIL DAN PEMBAHASAN}

Pemilihan model dilakukan untuk memilih model mana yang dapat diambil dalam melakukan pengolahan data. Untuk itu dilakukan pengujian antara chow test dengan hausman test.berikut hasil dai kedua uji tersebut :

Uji Spesikasi Pemilihan Model

Tabel 1

Hasil Uji Chow dengan Likelihood Ratio

\begin{tabular}{lrrr}
\hline Effects Test & Statistic & d.f. & Prob. \\
\hline Cross-section F & 9.357560 & $(8,33)$ & 0.0000 \\
Cross-section Chi-square & 53.294895 & 8 & 0.0000 \\
\hline
\end{tabular}

Sumber: output eviews 8

Dalam melakukan pengujian diatas terdapat nilai probability 0,0000 yaitu menunjukkan nilai yang signifikan namun saat dilakukan pengujian uji asumsi klasik terdapat gejala pada salah satu alat uji sehingga tidak mengahasilkan hasil yang mampu menjelaskan variabel dan uji di berhentikan hanya sampai disitu.

Selain itu dilakukan uji hausman test yang mana memilih antara Random Effect dengan Common Effect terlihat hasil seperti berikut:

\section{Tabel 2}

Hasil Uji Hausman test

\begin{tabular}{|c|c|c|c|}
\hline Test Summary & $\begin{array}{l}\text { Chi-Sq. } \\
\text { Statistic }\end{array}$ & Chi-Sq. d.f. & Prob. \\
\hline Cross-section random & 2.035538 & 3 & 0.5651 \\
\hline
\end{tabular}

Sumber: output eviews 8

Dalam hasil uji hausman test yang mana dilakukan untuk memilih model mana yang lebih baik digunakan antara Fixed Effect dengan Random Effect terdapat hasil probability 0.5651 besar dari 0.05.maka effect Random baik digunakan. Saat dilakukan uji asumsi klasik keempat uji lolos dari gejala- 
gejala yang memungkinkan dapat mempengaruhi data sehingga effect ini baik digunakan dibandingkan dengan Common Effect dan Fixed Effect.

Uji Spesifikasi Random Effect

Tabel 3

Uji Spesifikasi Random Effect

\begin{tabular}{lccc}
\hline Test Summary & $\begin{array}{c}\text { Chi-Sq. } \\
\text { Statistic }\end{array}$ & Chi-Sq. d.f. & Prob. \\
\hline Cross-section random & 2.035538 & 3 & 0.5651 \\
\hline
\end{tabular}

Sumber: output eviews 8

Pada tabel 4.8 terlihat nilai probability untuk cross section adalah 0,5651 yang mana > dari 0,05 artinya 95\% random effect model merupakan model yang sesuai.

Tabel 4

Hasil Uji Regresi Data Panel

\begin{tabular}{crrrr}
\hline Variable & Coefficient & Std. Error & t-Statistic & Prob. \\
\hline C & 1.808329 & 0.976898 & 1.851093 & 0.0714 \\
X1 & -0.019666 & 0.114223 & -0.172169 & 0.8642 \\
X2 & 0.138380 & 0.075018 & 1.844624 & 0.0723 \\
X3 & -0.057779 & 0.064439 & -0.896646 & 0.3751 \\
\hline
\end{tabular}

Sumber: output eviews 8

Nilai koefisien Dewan Komisaris (X1) adalah sebesar -0.019666 menunjukan hasil yang negatif yang berarti setiap bertambahnya jumlah anggota dewan komisaris sebanyak 1 orang maka akan menurunkan ROA sebesar -0.019666 .

Nilai koefisien Komite Audit (X2) adalah sebesar 0.138380 menunjukan hasil yang positif yang berarti setiap bertambahnya jumlah anggota Komite Audit sebanyak 1 orang maka akan meningkatkan ROA sebesar 0.138380 .

Nilai koefisien Leverage (X3) adalah sebesar -0.057779 menunjukan hasil yang negatif yang berarti setiap bertambahnya jumlah hutang sebanyak 1 lembar maka akan menurunkan ROA sebesar -0.057779.

Statistik Deskriptif Variabel penelitian

Berdasarkan hasil analisis deskriptif statistic, maka data karekteristik sampel yang digunakan didalam penelitian ini meliputi : jumlah sampel (N), rata-rata sampel (mean), nilai maksimum, nilai minimum serta standar deviasi $(\sigma)$ untuk masing-masing variabel.

\section{Tabel 5}

Hasil Uji Deskripsi Statistik

\begin{tabular}{lccccc}
\hline Variabel & N & Minimum & Maksimum & Mean & Standar deviasi \\
\hline X1 (Dewan Komisaris) & 45 & 3 & 9 & 6,7 & 1,5 \\
X2 (Komite Audit) & 45 & 2 & 8 & 4,6 & 1,6 \\
X3 (Leverage) & 45 & 3,79 & 12,15 & 7,3 & 2,2 \\
Y(ROE) & 45 & 0,18 & 3,41 & 1,9 & 0,8 \\
\hline
\end{tabular}

Sumber: output eviews 8 
Tabel 5 menggambarkan deskripsi statistik untuk masing-masing variabel yang digunakan jumlah data yang digunakan dalam penelitian ini adalah sebesar 45 data. Rata-rata jumlah dewan komisaris perusahaan sector keuangan adalah 6,7 Rata-rata komite audit 4,6. Rata-rata Leverage yaitu 7,3. dan rata-rata $\mathrm{ROA}$ adalah 1,9 .

Tabel 6

Uji Normalitas

\begin{tabular}{cc}
\hline Jarque-Bera & 1.281391 \\
\hline Probabiliti & 0.526926
\end{tabular}

Sumber: output eviews 8

Dilihat dari tabel 6 diatas pada probability variabel independen bernilai 0.526926 yang menujukkan bahwa probabilitas $>0.05$ berarti data berdistribusi normal.

Tabel 7

Uji Multikolinearitas

\begin{tabular}{lccc}
\hline & X1 & X2 & X3 \\
\hline X1 & 1,000000 & 0,526766 & $-0,202001$ \\
X2 & 0,526766 & 1,000000 & 0,073755 \\
$\mathbf{X 3}$ & 0,202001 & 0,073755 & 1,000000 \\
\hline
\end{tabular}

Sumber: output eviews 8

Berdasarkan hasil olahan data pada tabel 7 terlihat nilai korelasi antara sesama variabel independen $<0,8$ sehingga dapat dikatakan bahwa sesama variabel independen tidak memiliki hubungan multikolinearitas.

Tabel 8

Uji Autokolerasi

\begin{tabular}{lc}
\hline Model & Durbin Watson \\
\hline $\mathbf{1}$ & 1.547960 \\
\hline
\end{tabular}

Sumber: output eviews 8

Dari Uji Durbin-Watson pada tabel 8 terlihat bahwa tidak terjadi autokolerasi karena nilai DW antara $-2<1,547960<2$.

Tabel 9

Uji Heteroskedastisitas

\begin{tabular}{crc}
\hline Variable & Coefficient & Prob. \\
\hline C & 0.759028 & 0.0576 \\
X1 & -0.021791 & 0.6689 \\
X2 & 0.011108 & 0.8169 \\
X3 & -0.000587 & 0.9842 \\
\hline
\end{tabular}

Sumber: output eviews 8

Pada tabel 9 terlihat tidak terjadi heteroskedastisitas karena nilai probability $>0,05$. 
Tabel 10

hasil uji regresi data panel

\begin{tabular}{|c|c|c|c|c|}
\hline Variable & Coefficient & Std. Error & t-Statistic & Prob. \\
\hline $\mathbf{C}$ & 1.808329 & 0.976898 & 1.851093 & 0.0714 \\
\hline $\mathbf{X} 1$ & -0.019666 & 0.114223 & -0.172169 & 0.8642 \\
\hline $\mathrm{X} 2$ & 0.138380 & 0.075018 & 1.844624 & 0.0723 \\
\hline X3 & -0.057779 & 0.064439 & -0.896646 & 0.3751 \\
\hline \multicolumn{5}{|c|}{ Weighted Statistics } \\
\hline $\begin{array}{l}\text { R-squared } \\
\text { Adjusted R- }\end{array}$ & 0.089491 & \multicolumn{2}{|c|}{ Mean dependent var } & 0.515277 \\
\hline squared & 0.022868 & \multicolumn{2}{|c|}{ S.D. dependent var } & 0.468124 \\
\hline S.E. of regression & 0.462740 & \multicolumn{2}{|c|}{ Sum squared resid } & 8.779267 \\
\hline F-statistic & 1.343247 & \multirow{2}{*}{\multicolumn{2}{|c|}{ Durbin-Watson stat }} & 1.547960 \\
\hline Prob(F-statistic) & 0.273608 & & & \\
\hline
\end{tabular}

Sumber: output eviews 8

Nilai koefisien Dewan Komisaris (X1) adalah sebesar -0.019666 menunjukan hasil yang negatif yang berarti setiap bertambahnya jumlah anggota dewan komisaris sebanyak 1 orang maka akan menurunkan ROA sebesar -0.019666

Nilai koefisien Komite Audit (X2) adalah sebesar 0.138380 menunjukan hasil yang positif yang berarti setiap bertambahnya jumlah anggota Komite Audit sebanyak 1 orang maka akan meningkatkan ROA sebesar 0.138380 .

Nilai koefisien Leverage (X3) adalah sebesar -0.057779 menunjukan hasil yang negatif yang berarti setiap bertambahnya jumlah hutang sebanyak 1 lembar maka akan menurunkan ROA sebesar -0.057779.

\section{Uji Hipotesis}

\section{Uji koefisien Regresi secara Simultan (Uji f)}

Dari tabel dihasilkan nilai $F$-statistic sebesar 1.343247 dengan nilai signifikan probability $F$-statistic adalah 0.273608 . Hal tersebut mengidentifikasi bahwa semua variabel independen (Dewan Komisaris,Komite Audit,Leverage) berpengaruh signifikan tehadap variabel dependen (ROA).

\section{Uji Parsial (Uji t)}

Uji parsial digunakan untuk mengetahui variabel bebas yang berpengaruh signifikan secara individu terhadap variabel terikat. Dari tabel variabel yang signifikan ditandai oleh probabiliti f-statistik yaitu 0.273608 yang mana besar dari 0.05 sehingga dengan tingkat keyakinan $95 \%$ variabel yang signifikan mempengaruhi variabel terikat.

\section{Pembahasan}

\section{Pengaruh Dewan Komisaris terhadap Kinerja Keuangan (ROA)}

Dari tabel 10 dihasilkan nilai koefisien regresi untuk variabel dewan komisaris yang diproxy oleh (ROA) sebesar -0.19666 bertanda negatif dengan probability $0.0714>0,05$ yang berarti bahwa dewan komisaris mempunyai pengaruh negatif dan tidak signifikan terhadap probabilitas yang diproxy oleh ROA. Hal ini berarti jumlah dewan komisaris tidak berpengaruh terhadap ROA. 
Vafeas (2000) mengatakan bahwa selain kepemilikan manajerial, peranan dewan komisaris juga diharapkan dapat meningkatkan kualitas laba dengan membatasi tingkat manajemen laba melalui fungsi monitoring atas pelaporan keuangan.

Penelitian ini mendukung penelitian yang dilakukan Totok Dewayanto menyatakan bahwa ukuran dewan komisaris (BOC) berpengaruh negatif dan tidak signifikan terhadap kinerja keuangan perbankan, artinya antara ukuran dewan komisaris dengan kinerja keuangan perbankan tidak memiliki kontribusi yang nyata berpengaruh. Dengan demikian dapat disimpulkan hipotesis pertama ditolak.

\section{Pengaruh Komite Audit Terhadap Kinerja Keuangan (ROA)}

Hasil penelitian koefisien regresi dari Komite Audit sebesar 0.138380. Hal ini menunjukan Komite Audit mempunyai pengaruh positif terhadap kinerja keuangan (ROA). Probabilitas menunjukan lebih besar dari 0,05 yaitu 0.0723 yang artinya bahwa variabel Komite Audit berpengaruh positif dan tidak signifikan terhadap kinerja keuangan (ROA).

Penelitian ini memperkuat penelitian yang dilakukan oleh Maria Fransisca Widyati (2013) mengatakan bahwa komite audit yang diukur dengan jumlah komite audit tidak memiliki pengaruh yang signifikan terhadap kinerja keuangan.Begitu juga dengan Penelitian yang dilakukan oleh Hamonangan Siallagan (2006) menunjukkan bahwa dengan tingkat keyakinan $95 \%$, komite audit memiliki pengaruh terhadap kualitas laba. Hasil ini menunjukkan bahwa dengan adanya komite audit dalam perusahaan maka discretionary accrual semakin rendah (discretionary accrual yang rendah maka kualitas laba tinggi). Hal ini jelas mengatakan bahwa jumlah komite audit tidak menjamin keefektifan kinerja komite audit dalam melakukan pengawasan terhadap kinerja keuangan perusahaan. Dengan demikan hipotesis kedua diterima.

\section{Pengaruh Leverage terhadap Kinerja Keuangan (ROA)}

Dari tabel 10 dihasilkan dari nilai koefisien regresi untuk variabel leverage yang diproxy oleh ROA sebesar -0.057779 bertanda negatif dengan nilai probability $0.3751<0,05$ yang berarti bahwa Leverage mempunyai pengaruh negatif dan signifikan terhadap kinerja keuangan (ROA). Hal ini menunjukkan bahwa semakin besar tingkat Leverage berarti setiap meningkatnya jumlah hutang sebanyak 1 lembar maka akan menurunkan ROA sebesar 0.3751. Sebaliknya jika menurun jumlah tingkat hutang sebanyak 1 lembar maka akan meningkatkan ROA sebesar 0178497.

Penelitian ini mendukung penelitian yang dilakukan oleh Ika yulianawati (2014) mengatakan bahwa leverage berpengaruh negatif terhadap kinerja keuangan karna ditemukan pada tingkat signifikan 5\%. Dan Penelitian ini memperkuat penelitian yang dilakukan oleh Dian Agustia (2013) yang mengatakan bahwa leverage berpengaruh negatif yang signifikan terhadap manajemen laba karena semakin tinggi proporsi hutang dibandingkan proporsi aktiva akan cenderung melakukan manipulasi dalam bentuk laporan keuangan manajemen laba. Begitu juga 
dengan penelitian yang dilakukan oleh Arum Purwandari (2012) bahwa leverage berpengaruh negatif terhadap kinerja keuangan perusahaan. Dengan demikian dapat disimpulkan hipotesis ketiga diterima.

\section{KESIMPULAN}

Dewan Komisaris menghasilkan hipotesis yang berpengaruh negatif dan tidak signifikan. hipotesis pertama ditolak.Komite Audit memberikan hipotesis yang positif dan tidak signifikan. hipotesis kedua diterima. Leverage memberikan hipotesis yang berpengaruh negatif dan tidak signifikan terhadap kinerja keuangan.hipotesis ketiga ditolak.

\section{UCAPAN TERIMAKASIH}

Dalam penyusunan penelitian ini, penulis menyadari bahwa tanpa bimbingan dan bantuan dari berbagai pihak, penulis belum tentu dapat menyelesaikan penelitian ini. Untuk itu ucapan terimakasih yang sebesarbesarnya penulis sampaikan kepada: Bapak Febryandhie Ananda, SE, M.Si selaku ketua STIE "KBP” Padang yang telah memberikan bimbingan dan fasilitas selama penulis menjadi mahasiswi. Ibu Lidya Martha, SE, MM selaku wakil ketua dan sekaligus penasihat akademik angkatan 2013. Ibu Febsri Susanti, SEI, MM selaku ketua program studi manajemen Sekolah Tinggi Ilmu Ekonomi "Keuangan, Perbankan dan Pembangunan" Padang. Ibu Aminar Sutra Dewi, SE, M.Si selaku Dosen Pembimbing penulis, yang telah membimbing penulis dari awal skripsi sampai saat sekarang ini, membimbing penulis dengan penuh kesabaran, terimakasih atas segala kesempatan yang Ibu berikan semoga nasehat-nasehat yang Ibu berikan member manfaat bagi saya selamanya.

\section{DAFTAR REFERENSI}

Afriyeni, A., \& Marlius, D. (2017). Analisis Pengaruh Harga Saham Perdana Terhadap Abnormal Return Yang Diterima Investor Studi Pada Bursa Efek Indonesia. https://doi.org/10.31219/osf.io/8z7hx

Afriyeni, A., \& Marlius, D. (2018). Analisis Pengaruh Informasi Prospektus Perusahaan Terhadap Initial Return Saham Pada Pasar Perdana Di Bursa Efek Indonesia. https://doi.org/10.31219/osf.io/kt6c4

Afriyeni, A., \& Marlius, D. (2019). Analisis Faktor-Faktor Yang Berpengaruh Terhadap Ketepatan Waktu Penyampaian Laporan Keuangan Pada Perusahaan Yang Listing Di Bursa Efek Indonesia. https://doi.org/10.31219/osf.io/rv4qf

Afriyeni, A., \& Marlius, D. (2019). Analisis Tingkat Pengembalian Dan Risiko Investasi (Studi Pada Industri Manufaktur Yang 
$\begin{array}{lllll}\text { Terdaftar Di } & \text { Bursa } & \text { Efek }\end{array}$ https://doi.org/10.31219/osf.io/cfb92

Agustia, D. (2013). Pengaruh Faktor Good Corporate Governance, Free Cash Flow, dan Leverage Terhadap Manajemen Laba. Jurnal Akuntansi Dan Keuangan, 15(1), 27-42. https://doi.org/10.9744/jak.15.1.27-42

Dewi AS. (2014). Pengaruh Good Corporate Governace dan Leverage Terhadap Kinerja keuangan Perbankan Yang terdaftar di BEI. Manajemen

D., \& Dewi, A. S. (2018). Pengaruh Penerapan Good Corporate Governance Terhadap Kinerja Keuangan Perbankan Yang Terdaftar Di Bursa Efek Indonesia. https://doi.org/10.31219/osf.io/w5agv

Lestari, E. D. (2011). Pengaruh Good Corporate Governance Terhadap Kinerja Keuangan (Studi Kasus pada Perusahaan Perbankan yang Terdaftar di Bursa Efek Indonesia Tahun 2007-2009).

Purwandari, A. (2012). Pengaruh Profatibilitas, Leverage, Struktur Kepemilikan Dan Status Perusahaan Terhadap Pengungkapan Laporan Keuangan Pada Perusahaan.

Putri, A. D., \& Mayliza, R. (2019). Pengaruh Good Corporate Governance Dan Leverage Terhadap Kinerja Keuangan Pada Perbankan Yang Terdaftar Di BEI. https://doi.org/10.31219/osf.io/b8he7

Sari, I. (2010). Governance Terhadap Kinerja Perbankan.

Siallagan, H., \& Machfoedz, M. (2006). Mekanisme Corporate Governance, Kualitas Laba dan Nilai Perusahaan. Simposium Nasional Akuntansi 9 Padang, (61), 23-26.

Totok, D. (2010). Pengaruh Mekanisme Good Corporate Governance Terhadap Kinerja Perbankan Nasional. Manajemen.

Ujiyantho, M. A., \& Agus Pramuka, B. (2007). Mekanisme Corporate Governance, Manajemen Laba dan Kinerja Keuangan (studi pada perusahaan go publik sektor manufaktur). Simposium Nasional Akuntansi X, (Juli), 1-26.

Widyati, M. F. (2013). Pengaruh Dewan Direksi, Komisaris Indepeden, Komite Audit, Kepemilikan Manajerial dan Kepemilikan Institusional terhadap Kinerja Keuangan. Jurnal Ilmu Manajemen, 1(1), 234-249. 
Yulianawati ika. (2014). Pengaruh Good Corporate Governance Dan Leverage Terhadap Kinerja Keuangan. Jurnal Manajemen. 